\title{
DEIKSIS DALAM BAHASA USING DI KABUPATEN BANYUWANGI
}

\author{
Syuhadak [1], Bambang Wibisono [2], Agus Sariono [3]
}

[1] syuhadaklaros@gmail.com, [2] bambangwib@yahoo.com, [3] agussariono11@gmail.com Magister Linguistik Fakultas Ilmu Budaya Universitas Jember

Jember, Jawa Timur, Indonesia

\begin{abstract}
Deixis is one of the lingual phenomenon which have the universal function as one of the center of something. This article is aimed to describe the using of expresion in the deixis of Banyuwangi, Using languange. The descriptive method is using to describe the phenomenon. The data were callected participation observation, interview, and introspekt reflektive. The data were analysed byteknik pilah unsur penentu and hubung bandingtechnical. The result from this discusion is the using of promina persona in Osing language is influenced by the age, and heredity between the participants factors. Ekspression places on Using language will be deixis if used based on speakers prespektiv. Time ekspression have gain if the speaker as a deixis core when speech produses. That become a speech as time core, so time place by events that before, on, or after speech. Social deixis in Using language use on language greating be related on nick name, family, tittle, office, rank, name, and pronouns. Demontrativ locativ discourse deixis used to related of part discourse referred with the places. By referred on part before speech and after speech.
\end{abstract}

Keywords: deixis, language, Using, Banyuwangi

\section{PENDAHULUAN}

Indonesia adalah negara yang sangat kaya dengan bahasa daerah karena memiliki 719 bahasa yang sangat beragam (Lewis et al, 2015). Berdasarkan laporan hasil penelitian Kekerabatan dan Pemetaan Bahasa-Bahasa di Indonesia yang dilakukan oleh Badan Bahasa pada tahun 2008, telah berhasil diidentifikasi sejumlah 442 bahasa. Hingga tahun 2011, tercatat terjadi penambahan sejumlah 72 bahasa sehingga jumlah keseluruhannya menjadi 514 bahasa. Jumlah tersebut masih dapat bertambah karena masih ada beberapa daerah yang belum diteliti.

Salah satu bahasa daerah yang masih hidup pada saat ini adalah bahasa Using. Bahasa Using merupakan bahasa yang dituturkan oleh masyarakat yang tinggal di beberapa wilayah atau kecamatan di Banyuwangi selain bahasa Jawa dan Madura. Bahasa yang pada saat ini dipergunakan oleh sebagian penduduk Kabupaten Banyuwangi ini berkedudukan sebagai bahasa daerah kecil. Tidak semua orang atau masyarakat di Banyuwangi menggunakan bahasa Using. Dari 24 kecamatan yang ada di Kabupaten Banyuwangi, hanya sekitar 13 kecamatan yang masih aktif menggunakan Bahasa Using, yaitu Kabat, Rogojampi, Giri, Glagah, Kalipuro, Srono, Cluring, Songgon, Gambiran, Singojuruh, Licin, sebagian Genteng, serta Sebagian Banyuwangi Kota (Mukarromah, 2016, h. 1182).

Salah satu usaha pelestarian bahasa daerah adalah dengan melakukan penelitianpenelitian yang dapat menambah wawasan kebahasaan, terutama berkaitan dengan bahasa daerah yang diteliti. Salah satu kajian yang penting dilakukan, dalam kaitannya dengan bahasa yang dipergunakan di Banyuwangi adalah penelitian tentang deiksis dalam bahasa Using. Setiap bahasa memiliki ekspresi deiksisnya masing-masing yang dapat difungsikan untuk mengacu sesuatu 
dalam berkomunikasi. Deiksis merupakan salah satu hal yang amat penting sehubungan dengan penggunaan bahasa. Hal tersebut sebagaimana yang dikemukakan Yule (1996, h. 9) deiksis merupakan upaya pengacuan melalui penggunaan bahasa. Deiksis sebagai salah satu sub-bidang pragmatik, urgensinya amat jelas pada penggunaan bahasa. Melakukan komunikasi melalui wahana bahasa di antara sesama penggunanya tidak dapat berlangsung secara efektif dan efisien tanpa kehadiran deiksis di dalamnya Huang (2007, h. 132), Hasibuan (2011, h. 38).

Penelitian mengenai deiksis bukanlah hal baru, sudah ada peneliti sebelumnya yang meneliti masalah tersebut. Namun, penelitian yang khusus mengkaji tentang deiksis dalam bahasa Using belum pernah dilakukan. Kajian yang memiliki keterkaitan dengan perihal deiksis dalam bahasa Using yaitu, Maesaroh (2015) yang berjudul "Penggunaan Bentuk Lingual Salam dan Sapaan dalam Masyarakat Using di Kecamatan Rogojampi Kabupaten Banyuwangi". Dalam kajian tersebut selain membahas bentuk lingual salam juga dibahas perihal penggunaan sapaan yang relevan dengan ekspresi deiksis sosial yang peneliti gunakan sebagai pembanding dalam kajian ini.

Adapun penelitian yang relevan dengan kajian ini yaitu, Purwo (1984) yang berjudul "Deiksis dalam Bahasa Indonesia", dalam bahasa Indonesia liputan kajian deiksis masih berada pada seputar tiga jenis deiksis, berupa deiksis orang, deiksis tempat, dan deiksis waktu. Hasibuan (2011) yang berjudul "Deiksis dalam Bahasa Mandailing".Dalam bahasa Mandailing mengenal deiksis persona, deiksis tempat, deiksis waktu, deiksis sosial, dan deiksis wacana. Sahid (2011) yang berjudul "Deiksis dalam Bahasa Madura di Desa Kapongan Kabupaten Situbondo". Dalam kajian tersebut dibahas tentang pemakaian dan pemaknaan deiksis yang terdapat dalam bahasa Madura, di antaranya yaitu deiksis pronomina persona dan nama diri, deiksis pronominal demonstratif dan deiksis waktu. Jadi,dalam kajian ini, peneliti ingin mengungkap keunikan komparatif penggunaan deiksis yang terdapat dalam bahasa Using.

Menurut pengamatan awal peneliti, bahasa Using yang tidak mengenal hierarki bahasa seperti halnya bahasa Jawa, menempatkan mitra tutur pada hubungan yang sama atau egaliter. Perbedaan usia, gender, pangkat, dan jabatan tidaklah melahirkan hierarki dalam berbahasa. Namun demikian, bukan berarti bahasa Using tidak memiliki kesopanan atau kesantunan dalam berbahasa. Bahasa Using memiliki bentuk hormat sederhana atau disebut dengan besiki, atau kromo dalam bahasa Jawa. Bentuk hormat sederhana tersebut direpresentasikan dalam pemilihan dan penggunaan diksi atau pilihan kata tertentu, salah satu di antaranya yaitu penggunaan ekspresi deiksis. Keinginan untuk memperoleh informasi perihal penggunaan deiksis dalam bahasa Using dan keunikan yang terdapat di dalamnya mendasari upaya penulis untuk mendeskripsikannya menjadi sebuah kajian.

\section{METODE}

Metode yang digunakan dalam penelitian ini adalah metode deskriftif. Sudaryanto (1993, h. 62) menyatakan, bahwa metode deskriptif adalah metode yang dilakukan semata-mata hanya berdasarkan pada fakta yang ada atau fenomena yang secara empiris hidup pada penuturpenuturnya.

Metode analisis data dalam penelitian ini menggunakan metode padan dengan teknik pilah unsur penentu dan hubung banding. Cara padan referensial digunakan karena unsur penentunya berupa kenyataan yang ditunjuk oleh bahasa atau referen bahasa. Melalui daya pilah ini, peneliti menganalisis wacana-wacana yang berupa tuturan atau percakapan berdasarkan konteks situasi, hubungan pembicara dan pendengar, dan topik pembicaraannya. Pada tahapan ini, data yang berupa ekspresi deiksis diklasifikasikan berdasarkan jenis-jenis deiksis yaitu deiksis persona, deiksis tempat, deiksis waktu, deiksis sosial dan deiksis wacana.

Penelitian ini dilakukan dan difokuskan di Desa Gintangan yang terletak di Kecamatan Rogojampi Kabupaten Banyuwangi. Kecamatan Rogojampi sendiri terdiri dari 18 desa atau kelurahan, yang mayoritas masyarakatnya menggunakan Bahasa Using.

\section{DISKUSI DAN TEMUAN}

Penggunaan ekspresi deiksis yang terdapat dalam bahasa Using di Banyuwangi yang meliputi, deiksis persona, deiksis tempat, 
deiksis waktu, deiksis sosial dan deiksis wacana, dapat dideskripsikan sebagai berikut.

\section{Deiksis Persona dalam Bahasa Using Pronomina Persona Pertama}

Di dalam bahasa Using, kata ganti untuk persona pertama tunggal digunakan isun 'saya' dan kula'saya'. Kata ganti ini boleh dipergunakan oleh siapa saja dalam percakapan sehari-hari. Dalam bahasa Using, kata ganti isun dianggap netral, semua tingkat usia (muda, tua, sebaya) boleh menggunakan kata ganti isun 'aku' dalam berbicara. Berikut contoh penggunaan deiksis persona pertama dalam tuturan.

\section{Data 1}

\section{Konteks :}

Pagi hari, 01 dan 02 berpapasan di jalan yang tidak jauh dari rumah 02 . 01 berkata kepada 02 bahwa ia baru saja dari rumah 02 tetapi tidak ada orang sama sekali. 01 dan 02 adalah saudara kandung, adik kakak.

\section{Tuturan :}

01 : "Isun buru bain teka umah rika, tapi sing ana uwong"

[isUn buru $\mathrm{b}^{\mathrm{y}}$ aIn təkJ $\mathrm{um}^{\mathrm{y}}$ ah riks, tapi sIn onว uwon]

'Saya baru saja dari rumah kamu, tetapi tidak ada orang'

02 : "Iya, isun mari teka belanja ning Sulik. Ayo merana maning!"

[Iyo, isUn mari təko bələnjo nIn sulik. Ayo? məronว manIy]

'Iya, saya baru saja belanja di tokonya Sulik). Ayo kesana lagi!'

01: "Sing wis, iki kesusu arep ning Banyuwangi"

[sIn wIs, iki kəsusu arəp nIn bañuwani] 'Tidak jadi, ini terburu-buru mau ke Banyuwangi'

Pada tuturan (1) merupakan penggunaan jenis deiksis persona orang pertama tunggal isun. Kata ganti ini boleh dipergunakan oleh siapa saja dalam percakapan sehari-hari. Dalam bahasa Using, semua tingkat usia (muda, tua, sebaya) boleh menggunakan kata ganti isun 'aku' dalam berbicara. Dalam tuturan (1) misalnya, 01 mengetahui bahwa 02 relatif sebaya usia dengannya, sehingga 01 sebagai penutur mengacu dirinya dengan menggunakan pronomina persona isun. Demikian sebaliknya, karena 02 mengetahui bahwa 01 relatif sebaya usia dengannya, maka 02 setelah beroleh giliran sebagai penutur mengacu dirinya sendiri dengan pronomina persona yang sama yaitu isun. Pada tuturan isun buru bain teka umah rika, tapi sing ana uwong dan iya isun mari teka belanja ning Sulik, kata isun dalam kalimat tersebut diucapkan oleh perempuan dewasa, kakak kepada adiknya yang menginformasikan bahwa dia baru saja dari rumah mitra tutur tetapi tidak ada orang sama sekali. Selanjutnya sang adik menjawab bahwa ia baru saja selesai belanja. Jadi, jelas kalau kata isun pada tuturan di atas referennya selalu berganti-ganti tergantung pada siapa yang menjadi pembicara.

\section{Data 2}

\section{Konteks}

Pagi hari, 01 berkunjung ke rumah 02 . Kebetulan 02 sedang berada di teras rumahnya sedang menyapu. 01 mengutarakan keinginannya untuk meminta daun kelor untuk dimasak. 01 dan 02 adalah keponakan kepada saudara tua perempuan (Bu De).

\section{Tuturan :}

01 : "Wak, kula ajeng nedi kelore"

[ $\mathrm{w}^{\mathrm{y}} \mathrm{ak}, \mathrm{kul}$ a ajəy nədi kelore]

'Wak, saya mau minta daun kelornya'

02 : "Njuwuta wis Lik (thulik)"

[njUwUto wIs lI?]

'Ambil saja sudah Nak'

Pada tuturan (2), Wak, kula ajeng nedi kelore. Kata kula diucapkan oleh perempuan dewasa kepada saudara tua perempuan $(\mathrm{Bu}$ De) dari ayah mitra tutur, yang meminta daun kelor untuk dimasak. kata kula 'saya' hanya dipergunakan oleh seseorang yang usianya lebih muda kepada seseorang yang dituakan dan dihormati atau dimuliakan. Masyarakat Using yang dikenal tidak memiliki hierarki bahasa namun ternyata masih tetap memiliki bentuk hormat atau kesantunan dalam memperlakukan mitra tuturnya.

Pronomina persona pertama jamak dalam bahasa Using menggunakan isun-rika 'kita'. Pronomina ini mengacu kepada penutur dan mitra tutur yang terdapat di dalam lingkup saat tuturan. Kata ganti isunrikadigunakan dalam situasi hubungan normal atau akrab dengan tidak terlalu terikat kepada pertimbangan perbedaan usia di antara partisipan. Penutur yang usianya lebih muda, sebaya atau seumuran, ataupun lebih tua dari orang yang menjadi mitra tuturnya dapat menggunakan kata ganti isun rika. 


\section{Data 3}

\section{Konteks}

Malam hari, 01 dan 02 sedang berada di dalam rumah. 01 bermaksud menghadiri pernikahan bersama keluarganya. Namun akhirnya 01 hanya mengajak suaminya. 01 dan 02 adalah istri dan suami.

\section{Tuturan :}

\section{1 : "Ayo wis isun ambi rika bain hang} merana!"

[ayo? wIs isUn ambi rikJ $\mathrm{b}^{\mathrm{y}}$ aIn hay məronj]

'Ayo sudah, kita saja yang ke sana!'

02 : "Iya wis, keloron bain"

[iyo wIs, kəloron $b^{\mathrm{y}}$ aIn]

'Iya sudah, berdua saja'

Pada tuturan (3), kata isun rika referennya mengacu kepada orang yang sedang berbicara, yaitu penutur dan menyertakan juga mitra tutur di dalamnya. Pada tuturan (3), ayo wis isun ambi rika bain hang merana. Penutur adalah seorang perempuan dewasa (istri) dan mitra tutur adalah laki-laki dewasa yang relatif lebih tua (suami), yang mengajak untuk menghadiri acara pernikahan dengan berdua saja tanpa mengajak anaknya yang kecil.

\section{Pronomina Persona Kedua}

Bahasa Using menggunakan pronomina persona kedua hira, sira atau ira, rika, ndika, sira kabeh, dan rika kabeh. Hira atau sira, rika dan ndika 'kamu' untuk kata ganti persona kedua tunggal. Sira kabeh dan rika kabeh'kalian' untuk kata ganti persona kedua jamak.

\section{Data 4}

\section{Konteks :}

Malam hari, di depan rumah 02. 01 yang tahu 02 baru dating dari bepergian menanyakan kapan kedatangannya. 01 dan 02 adalah tetangga.

Tuturan :

$$
\begin{aligned}
& 01 \text { : "Sira wayakendi teka Hik?" } \\
& \text { (Hik panggilan untuk Hikmah) } \\
& \text { [sirs wayakəndi təko hik] } \\
& \text { 'Kamu kapan datang Hik' } \\
& 02 \text { : "Kene mau" } \\
& \text { [kene mau] } \\
& \text { 'Baru saja' }
\end{aligned}
$$

Data 5

\section{Konteks :}

Pagi hari, 01 sedang menyapu halaman rumahnya. Datang 02 naik sepeda motor melewati depan rumah 01. Bertanyalah 01 kepada 01.01 dan 02 adalah tetangga.

\section{Tuturan :}

$$
\begin{aligned}
& 01 \text { : "Teka endi rika iku?” } \\
& \text { [təkJəndi riko ikau] } \\
& \text { 'Dari mana kamu?' } \\
& 02 \text { : "Iki mari teka pasar" } \\
& \text { [iki mari təkJ pasar] } \\
& \text { 'Baru dari pasar' }
\end{aligned}
$$

\section{Data 6}

\section{Konteks :}

Pagi hari, 01 berkunjung ke rumah 02 karena lama sudah tidak bertemu. Saat bertemu, 01 menanyakan kabar 02 .

\section{Tuturan :}

01 : "Mbah, ndika sehat?"

[mb ${ }^{\mathrm{y}}$ ah, ndIko sehat?]

'Mbah, kamu sehat?'

02 : "Alhamdulillah sehat"

[Alhamdulillah schat]

'Alhamdulillah sehat'

Pada tuturan (4), Sira wayakendi teka Hik? Kata sira digunakan penutur dengan pertimbangan usia mitra tutur yang relatif sebaya atau seumuran dengannya. Penutur dan mitra tutur adalah seorang perempuan dewasa yang masih memiliki hubungan keluarga, yaitu mitra tutur yang tidak lain adalah sepupunya. Pada tuturan (5), teka endi rika iku?Kata rika digunakan penutur dengan pertimbangan usia mitra tutur yang relatif sebaya atau seumuran dengannya. Penutur dan mitra tutur adalah seorang perempuan dewasa yang merupakan warga satu dusun. Pada tuturan (6), Mbah, ndika sehat? Kata ndika digunakan penutur dengan pertimbangan usia mitra tutur yang lebih tua dengannya, dalam hal ini adalah orang yang dituakan. Mitra tutur adalah orang tua perempuan dari ayah (mbah) si penutur. Dalam tuturan (6), penutur bertanya perihal keadaan mitra tutur yang lama tidak pernah bertemu karena keberadaan mitra tutur yang berjauhan.

Bahasa Using menggunakan sira kabeh dan rika kabeh 'kalian', untuk kata ganti persona kedua jamak. Dalam bahasa Using, kata ganti persona kedua jamak tersebut memiliki makna yang sama, yaitu kalian, tetapi pemakaian kata ganti tersebut dapat menunjukkan perbedaan usia antara penutur dengan lawan tutur. Kata ganti persona sira 
kabeh dipakai untuk menyapa orang kedua jamak yang usianya lebih muda daripada penutur, atau penutur relatif sebaya dengan mitra tutur (masih anak-anak atau pemuda). Rika kabeh dipakai untuk menyapa orang kedua jamak yang memiliki usia lebih tua, atau penutur dan mitra tutur memiliki usia yang relatif sebaya.

\section{Data 7}

\section{Konteks :}

Malam hari, lima orang anak les di rumah 01. Selesai belajar, 01 mendoakan mereka semua supaya nanti menjadi orang sukses.

\section{Tuturan :}

01 : "Muga-muga sira kabeh iki mbesok sukses!"

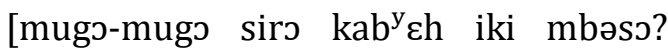
sukses]

'Mudah-mudahan kalian ini nanti sukses'

02 : "Amin"

[amin]

'Amin'

Pada tuturan (7) kata sira kabeh referennya mengacu kepada mitra tutur lima anak yang les. Tuturan (7), berasal dari penutur yang mendoakan mitra tutur, mudahmudahan kelak menjadi orang yang sukses. Pada tuturan tersebut, sira kabeh dipergunakan untukmitra tutur yang memiliki usia lebih muda daripada penutur.

\section{Pronomina Persona Ketiga}

Pronomina persona yang tergolong dalam kelompok orang ketiga dalam bahasa Using yaitu iyane, lare iku, dan uwong iku "dia" sebagai persona ketiga tunggal dan lare iku, uwong iku sebagai persona ketiga jamak.

\section{Data 8}

\section{Konteks :}

Sore hari, 01 dan 02 sedang duduk di teras rumah. Tiba-tiba datang 03 yang baru datang dari kuliah, berjalan di depan mereka.

\section{Tuturan :}

01 : "Dewi iku kuliahe geratis ya Mbok" [dewi iku kuliahe gəratis ya mbs?] 'Dewi itu kuliahnya gratis ya Mbak'

02 : "Iya, dibayari pemerintah. Iyane iku pinter, dadi ulih beasiswa"

[iyo, dibayari pəmərintah. Iyane iku pintər, dadi UlIh beasiswa]

'Iya, dibiayai pemerintah. Dia itu pandai, jadi dapat beasiswa'

\section{Data 9}

Konteks :

Siang hari, 01 duduk di depan rumahnya. Datang 02 menghampirinya. Lalu 01 menyuruh 02 untuk melihat siapa anak yang menangis itu.

\section{Tuturan :}

01 : "Hah, delengen sapa lare iku! Nangis bain sakat mau"

[hah, dəleyən sэpэ lare iku!nayIs $b^{\mathrm{y}}$ aIn sakat mau]

'Hah, lihatlah siapa anak itu! Menangis terus mulai tadi'

02 : "Anake Atun Bik Selamah"

[anake atun bI? selamah]

'Anaknya Atun Bik Selamah'

\section{Data 10}

\section{Konteks :}

Siang hari, 02 membeli rokok di toko 01. Ketika sedang melayani 02 , berjalanlah 03 melewati toko 01. Karena 01 tidak mengenali 03, maka bertanyalah 01 kepada 02 .

\section{Tuturan :}

01 : "Kang, wong iku sapa?"

[kay, wOy iku sops]

'Kak, orang itu sapa?'

02 : "Iku ya, lakine Tatik"

[iku ya, lakine tatlk]

'Itu lho, suaminya Tatik'

Pada tuturan (8), kata iyane referennya mengacu kepada orang yang ditunjuk atau yang dimaksudkan oleh penutur yaitu Dewi. Pada tuturan iyane iku kan pinter, dadi oleh beasiswa, kata iyanemengacu kepada Dewi, seorang perempuan dewasa yang tidak terlibat dalam tuturan antara penutur dan mitra tutur. Tuturan (8) menginformasikan bahwa ada seseorang yang bernama Dewi yang melanjutkan kuliah gratis karena mendapatkan beasiswa dari pemerintah atas prestasinya.

Tuturan (9), kata lare iku referennya mengacu kepada seorang anak yang ditunjuk atau dimaksudkan oleh penutur. Pada tuturan Hah, delengen sapa lare iku! Nangis tok sakat mau, kata lare iku mengacu kepada seorang anak berumur 5 tahun yang sedang menangis. Tuturan (9) menginformasikan bahwa ada seorang anak dari salah satu tetangga yang sedang menangis tiada henti-hentinya.

Sedangkan pada tuturan (10), kata wong iku referennya mengacu kepada orang yang ditunjuk atau dimaksudkan oleh penutur yaitu seorang laki-laki dewasa. Pada tuturan Kang, 
wong iku sapa?, kata wong iku mengacu kepada laki-laki dewasa yang tidak dikenal oleh penutur. Tuturan (10) penutur bertanya kepada mitra tutur tentang sosok laki-laki dewasa yang dilihatnya di depan toko. Lakilaki tersebut ternyata suami dari salah satu warga.

Untuk pronomina persona ketiga jamak dalam bahasa Using digunakan lare-lare ikudan wong-wong iku'mereka'. Dalam bahasa Using, kata ganti persona ketiga jamak dapat ditandai dengan reduplikasi pada kata ganti persona ketiga tunggal lare iku dan uwong iku.

\section{Data 11}

\section{Konteks :}

Malam hari di sebuah musola, 01 berkata kepada 02 perihal anak-anak yang bergurau saat pelaksanaan salat.

\section{Tuturan :}

01: "Lare-lare iku wayahe wong sembahyang muyab bain"

[lare-lare iku wayahe wэn səmb ${ }^{\mathrm{y}}$ ayan muyab b ${ }^{\mathrm{y}}$ ain]

'Anak-anak itu waktunya orang shalat bergurau saja'

02 : "Enggih niku ya"

[ə⿹glh niku ya?]

'Ya itu ya'

Pada tuturan (11), kata lare-lare iku referennya mengacu kepada anak-anak yang ditunjuk atau dimaksudkan oleh penutur. Tuturan lare-lare iku wayahe wong sembahyang muyab bain, kata lare-lare iku mengacu kepada tiga orang anak berusia $\begin{array}{lll}\text { sekitar } & 7 & \text { tahun.Tuturan }\end{array}$

menginformasikan bahwa ada tiga orang anak yang bergurau saat pelaksanaan salat Magrib di musala.

\section{Deiksis Tempat dalam Bahasa Using}

Berikut akan dipaparkan ekspresiekspresi yang menyatakan demonstratif (penunjuk) dalam bahasa Using, misalnya iki'ini', iku 'itu', ika'itu', ning kene'di sini', ning kono'di situ', ning kana'di sana', merene'ke sini', merono'ke situ', merana'ke sana', teka kene'dari sini', teka kono'dari situ', dan teka kana'dari sana'.

\section{Data 12}

\section{Konteks :}

Sore hari, 01 merapikan ruang tengah yang terlihat berantakan. 01 menemukan charger yang tergeletak di lantai. Bertanyalah 01 kepada 02 perihal penemuan charger tersebut.

Tuturan :

01 : “Iki anune sapa Im?"
[iki anune sopo im]
'Ini milik siapa Im?'

02 : "Anune Cak Farid Mak"

[anunə ca? farid ma?]

'Miliknya Kak Farid Bu'

Pada tuturan (12) demonstratif $i k i$ lazim digunakan untuk mengacu kepada objek tunggal yang lokasinya relatif dekat atau ada pada diri penutur. Tuturan (12) merupakan pertanyaan dari penutur kepada mitra tutur tentang siapa pemilik objek yang diacu atau digantikan dengan $i k i$. Dalam konteks tuturan tersebut, objek yang diacu dengan iki oleh penutur berada dekat dengan diri penutur seperti di depannya, disampingnya atau bahkan ada pada diri penutur sendiri misalnya ada di tangan penutur. Pengacuan objek tunggal dengan iki dalam konteks tuturan (12) berlangsung dengan disertai isyarat penggunaan gerakan anggota badan seperti tangan, muka yang mengarah ke objek atau mengeraskan volume suara pada saat tuturan.

\section{Data 13}

\section{Konteks :}

Pagi hari, 01 sedang memasak di dapur. 01 membutuhkan pisau untuk memotong sayuran. 01 menyuruh 02 untuk mengambilkan pisau yang berada tidak jauh dari dirinya.

\section{Tuturan :}

$01 \quad$ : "Juwutna iku Beng!"

[jUwUtno iku b $\left.{ }^{\mathrm{y}} \mathrm{E \eta}\right]$

'Ambilkan itu Nak!'

02 : "Enggih Mak"

[əทglh ma?]

'Iya Bu'

Pengacuan dengan demonstratif iku dilakukan terhadap objek tunggal yang lokasinya relatif jauh dari penutur dan terhadap objek yang dekat atau ada pada mitra tutur. Pada tuturan (13) merupakan penggunaan iku yang digunakan untuk mengacu kepada objek yang lokasinya relatif jauh dari penutur. Tuturan (13) merupakan perintah dari penutur kepada mitra tutur untuk mengambilkan pisau yang berada dekat dengan mitra tutur yang akan digunakan untuk memotong sayuran. Demonstratif $i k u$ oleh penutur digunakan untuk mengacu 
kepada objek pisau yang relatif jauh dari penutur dan dekat dengan mitra tutur.

\section{Data 14}

Konteks :

Siang hari, 01 dan 02 menyebar undangan kepada beberapa warga di dusunnya. Ketika 01 menyuruh 02 untuk memberikan undangan kepada salah satu warga, 02 salah masuk rumah seseorang yang dimaksud.

\section{Tuturan :}

01 : "Masa hang iku Rid, hang ika kok"

[moss hay iku rid, hay ikj kJ?]

'Bukan yang itu Rid, yang sana itu'

02 : "Ye, hang ika"

[ye, hay iko]

'Oh, yang sana itu'

Pengacuan dengan demonstratif ika dilakukan terhadap objek tunggal yang lokasinya jauh dari penutur dan mitra tutur pada saat tuturan. Karena faktor jauhnya lokasi yang diacu dengan menggunakan ika ke lokasi penutur dan mitra tutur maka perlu penyertaaan isyarat dalam penggunaannya. Tuturan (14) penutur menyuruh mitra tutur untuk memberikan undangan kepada salah satu warga yang ada di rumahnya, namun mitra tutur salah masuk rumah. Akhirnya penutur memberi tahu mitra tutur kalau rumah yang dimaksud adalah yang di sebelah sana seraya menunjukkan dengan isyarat tangan.

\section{Deiksis Waktu dalam Bahasa Using}

Setiap ekspresi lingual yang mengungkapkan konsep waktu akan bersifat deiksis apabila waktu peristiwa yang diacu oleh ekspresi tersebut ditautkan dengan lokasi waktu saat dituturkannya ekspresi tersebut. Dengan menjadikan saat tuturan sebagai pusat deiksis, mengimplikasikan bahwa lokasi waktu suatu peristiwa berada sesudah, bersamaan, atau sebelum saat tuturan, yang masing-masing merupakan ekspresi pengacu kepada waktu lampau, sekarang atau kini dan mendatang.

Ekspresi waktu dalam bahasa Using yang pengacuaannya kepada waktu lampau yaitu buru bain, mau, sore, sorene maning atau bengen temen, sabene, pas ika, danbengen.Ekspresi waktu yang pengacuaannya kepada waktu sekarang yaitu saiki dan dina iki. Sedangkan ekspresi waktu yang pengacuaannya kepada waktu mendatang yaitu mari iki, engko, engkisuk, emben, emben dawa, kapan-kapan dan mbesok. Berikut dikemukakan data penggunaan deiksis waktu dalam tuturan.

\section{Data 15}

Konteks :

Pagi hari, 01 berkunjung ke rumah 02. Ketika sampai di rumahnya, 02 sedang tidak berada di rumah. Selang beberapa waktu kemudian, 01 datang kembali ke rumah 02 dan ternyata 02 sudah berada di rumahnya.

\section{Tuturan :}

01 : "Buru bain hun teka kene tapi sing ana wong"

[buru b ${ }^{\mathrm{y}}$ aIn hUn təko kene tapi sIn эn woy]

'Baru saja saya dari sini tetapi tidak ada orang'

02 : "Iya, mari teka sawah kene mau"

[iyo, mari təkə sawah kene mau]

'Iya, habis dari sawah barusan'

\section{Data 16}

Konteks :

Siang hari, ketika 01 berkunjung ke rumah 02 . 01 mengatakan bahwa dirinya tadi pagi bertemu dengan ibu si 02 di pasar.

Tuturan :

01 : "Cak, mau isun kecaruk embah ning pasar"

[ca?, mau isUn kəcarUk əmb $^{\mathrm{y}} \mathrm{ah}$ nIn pasar]

'Kak, tadi saya bertemu mbah di pasar'

02 : "Iya, mau emak mula ning pasar"

[iys, mau әma? mulo nIn pasar]

'Iya, tadi ibu memang ke pasar'

Pada tuturan (15) pengacuan dengan

buru bain digunakan untuk mengacu kepada lokasi waktu lampau yang dekat dengan saat tuturan. Tuturan (15) merupakan penggunaan pengacuan buru bain pada periode pagi. Penutur menginformasikan kepada mitra tutur bahwa beberapa waktu yang lalu penutur datang ke rumah mitra tutur namun tidak ada orang yang bisa ditemui. Jarak lokasi waktu yang diacu pada saat tuturan tersebut diucapkan masih berada pada periode pagi yang sama.

Pada tuturan (16) ekspresi waktu mau digunakan untuk mengacu kepada lokasi waktu lampau yang relatif jauh dengan saat tuturan. Tuturan (16) merupakan penggunaan pengacuan mau pada periode waktu siang kepada lokasi waktu pada periode pagi. Tuturan (16) penutur menginformasikan 
kepada mitra tutur bahwa tadi pagi ia bertemu dengan ibu mitra tutur di pasar. Tuturan tersebut disampaikan penutur pada waktu sore hari. Jadi, jarak lokasi waktu acuan terjadi pada periode pagi dan sore, dalam periode waktu yang sama sehari semalam.

\section{Data 17}

Konteks :

Pagi hari, 01 bersiap akan berangkat bekerja ke kantor. 01 berkata kepada 02 akan berangkat lebih pagi dari biasanya dikarenakan cuaca mendung.

\section{Tuturan :}

01 : "Melaku saiki bain wis, selak udan"

[məlaku saiki $b^{\mathrm{y}}$ aIn wIs, səlak ud ${ }^{\mathrm{y}}$ an]

'Berangkat sekarang saja sudah, keburu hujan'

02 : "Magih isukya"

[magIh IsUk ya]

'Masih pagi ya'

\section{Data 18}

\section{Konteks :}

Sore hari, 01 bertemu 02 di rumahnya. 01 bercerita kepada 02 bahwa dirinya baru datang dari pasar, di sana ia melihat di manamana orang memegang $\mathrm{Hp}$.

\section{Tuturan :}

01 : "Saiki akeh wong duwe Hp"

[saiki akch woy duwe hp]

'Sekarang banyak orang mempunyai Hp'

02 : "Iya Mbok, paran maning regane murah" [iyo mbs? paran manIy rəgone murah]

'Iya Kak, apalagi harganya murah'

Pada tuturan (17), ekspresi waktu saiki digunakan untuk mengacu kepada lokasi waktu sekarang pada periode waktu yang digunakan untuk menyelesaikan tuturan. Tuturan (17) berasal dari penuturyang berkata kepada mitra tutur bahwa penutur akan berangkat ke kantor lebih awal dari biasanya dikarenakan cuaca mendung. Pada tuturan (18), ekspresi waktu saiki digunakan untuk mengacu kepada lokasi waktu sekarang pada periode waktu yang lebih lama dari itu, yang meliputi saat tuturan. Tuturan (18), berasal dari penutur yang menginformasikan kepada mitra tutur sekarang ini semakin banyak seseorang yang memiliki Hp. Jadi, periode waktu yang diacu dengan saiki pada tuturan (17) ruang lingkupnya lebih sempit yaitu terbatas pada waktu yang digunakan penutur untuk menyelesaikan tuturan. Sedangkan pada tuturan (18) ruang lingkupnya lebih luas tidak hanya digunakan penutur untuk menyelesaikan tuturan tetapi digunakan untuk mengacu kepada waktu yang periodenya dimulai dari waktu sebelum tuturan hingga periode waktu yang sama sesudah saat tuturan.

\section{Data 19}

\section{Konteks :}

Pagi hari, 01 bertemu dengan 02 di jalan saat olah raga pagi. 01 mengatakan kepada 02 bahwa setelah ini ia akan berkunjung ke rumah 02 karena ada sesuatu hal yang ingin dibicarakan dengannya.

\section{Tuturan :}

\section{1 : "Mari iki hun merana" [mari iki hUn mərono] 'Setelah ini saya ke sana' \\ 02 : "Ya hun enteni" [ya hUn ənteni] 'Ya saya tunggu'}

\section{Data 20}

\section{Konteks :}

Pagi hari, 01 bertemu 02 di jalan saat olah raga pagi. 01 mengingatkan 02 bahwa nanti sore waktunya latihan sepak bola. 01 mengharapkan 02 bisa datang untuk latihan.

\section{Tuturan :}

01 : "Aja lali engko wayahe latihan"

[jjo lali ə⿹ko wayahe latihan]

'Jangan lupa nanti waktunya latihan'

02 : "Ya muga-muga sing udan"

[yว mugo-mugo sIn ud $\mathrm{d}^{\mathrm{y}} \mathrm{an}$ ]

'Ya mudah-mudahan tidak hujan'

Pada tuturan (19), ekspresi waktu mari iki digunakan untuk mengacu terhadap lokasi waktu mendatang yang jaraknya relatif dekat dengan saat tuturan. Tuturan (19), berasal dari penutur yang menginformasikan kepada mitra tutur bahwa setelah ini ia akan ke rumahnya untuk membicarakan sesuatu hal. Jadi, periode waktu yang diacu dengan mari iki pada tuturan (19) mengacu pada waktu pagi sampai sebelum siang dalam periode waktu sehari semalam.

Pada tuturan (20), ekspresi waktu engko digunakan untukmengacu terhadap waktu mendatang, yang jaraknya ke saat tuturan melebihi batas periode bagian-bagian waktu dalam sehari semalam. Tuturan (20) penutur mengingatkan mitra tutur bahwa nanti sore waktunya latihan sepak bola. Penutur berharap mitra tutur bisa hadir dalam latihan tersebut. Dengan demikian, periode waktu yang diacu dengan engko tuturan (20) 
mengacu pada periode waktu dari bagianbagian sehari semalam, pagi ke sore.

\section{Deiksis Sosial dalam Bahasa Using}

Huang (2007, h. 166) mengatakan
bahwa ekspresi merepresentasikan deiksis sosial terdapat pada pronomina persona, bentuk sapaan, bentuk terikat, dan bentuk pilihan kata. Dalam tulisan ini hanya dibahas tentang ekspresi lingual deiksis sosial yang berupa kata sapaan. Sugono (2003, h. 77) menjelaskan enam bagian kata sapaan dalam bahasa Indonesia, yaitu 1) nama diri, menyebut nama orang seperti Ani, Budi dan lain sebagainya, 2) kata yang tergolong istilah kekerabatan, menyebut orang-orang yang masih memiliki hubungan darah atau saudara, seperti kakek, paman, bapak, ibu, kakak, adik dan lain sebagainya, 3) gelar kepangkatan atau profesi, seperti kepala desa, camat, guru, jenderal, kyai, sopir dan lain sebagainya, 4) kata nama, seperti tuan, nyonya, pangeran, Tuhan dan lain sebagainya, 5) kata nama pelaku, seperti peserta, pendengar, atau hadirin, dan 6) kata ganti persona, seperti saya, kamu, dia, dan lain sebagainya.

\section{Data 21}

Konteks :

Pagi hari, 01 berteriak memanggil 02 yang masih berada di dalam rumah. 01 dan 02 adalah tetangga. 01 bermaksud mengajak 02 berangkat takziah bersama.

\section{Tuturan :}

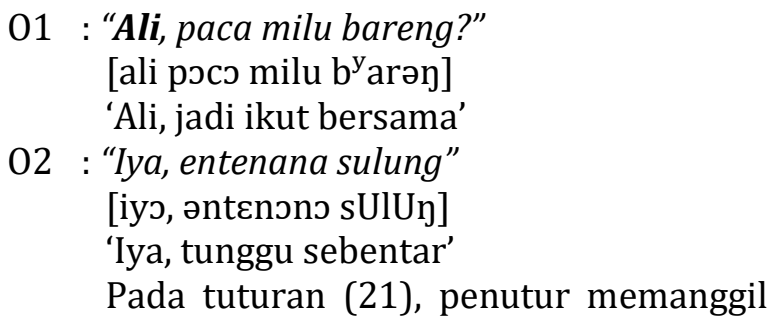
nama mitra tutur langsung dengan menyebut nama diri yang dimilikinya, yaitu Sri, tanpa sebutan kekerabatan, gelar atau panggilan kehormatan. Penyebutan seperti itu dalam masyarakat Using disebut dengan jambal. Penyebutan langsung pada nama diri seseorang karena pertimbangan usia yang sama atau seumuran dan usia yang lebih muda dari penutur. Dalam tuturan di atas, 01 dan O2 hubungan sosialnya adalah tetangga sebelah rumah yang usianya seumuran atau sebaya

\section{Data 22}

Konteks :

Sore hari, 01 bertanya kepada 02 yang berada di depan rumah. 02 adalah saudara muda lakilaki dari bapak atau ibu dari 01. 01 bertanya kepada 02 perihal keberadaan anaknya yang akan diajak bermain sepak bola.

Tuturan :

\section{1 : "Man Asan, Gofur enten?" [man asan, gofur entən] \\ 'Paman Asan, Gofur ada]}

02 : "Kaya ana ning njero kamar"

[kэyว onว nIn njəro kamar]

'Ada di dalam kamar sepertinya'

Selain penyebutan nama diri secara langsung, penyebutan nama diri dalam bahasa Using juga diiringi dengan penyebutan istilah kekerabatan. Pada tuturan (22), penutur memanggil nama mitra tutur dengan disertai penyebutan istilah kekerabatan Man Asan. Hal ini dikarenakan antara penutur dengan mitra tutur memiliki hubungan keluarga. Mitra tutur adalah saudara muda laki-laki dari bapak atau ibu. Man itu adalah kependekan dari paman.

\section{Data 23}

\section{Konteks :}

Siang hari, 01 sedang duduk di teras rumah. Tiba-tiba datang 02 yang lewat depan rumahnya. Melihat hal itu, 01 menyapa 02.

\section{Tuturan :}

01 : "Bik Ipuk, arep ning endi rika iku? Mampira pok!"

[bI? Ipuk, arəp nIn əndi riko ikau. mampIro pok]

'Bi Ipuk, mau kemana kamu itu? Silakan mampir!'

02 : "Iki arep tuku rujak, iya kesuwun".

[iki arəp tuku ruj ${ }^{\mathrm{y}}$ ak, iys kəsuwUn]

'Ini mau beli rujak. Iya, terima kasih'

Pada data (23), bentuk sapaan Ipuk yang dibicarakan oleh 02 memiliki nama asli Saripah. Panggilan Ipuk tersebut ia terima ketika masa remaja dari teman-temannya. Peristiwa tersebut dalam masyarakat Using dikenal dengan istilah wadanan [wadanan]. Dalam Kamus Bahasa Using wadanan berarti ejekan atau celaan. Wujud mengejek di sini maksudnya mengganti nama orang lain dengan nama yang lebih jelek untuk dijadikan lelucon.

Penggunaan sapaan nama diri dalam bahasa Using juga berkaitan dengan ciri fisik, profesi dan gelar yang terdapat dalam diri seseorang. Sapaan nama diri dengan ciri fisik 
berkaitan dengan keadaan atau kondisi yang terdapat pada tubuh seseorang, misalnya, lemu, gering, gedhe, cilik, duwur, pincang, moncong, ndombleh dan lain sebagainya. Sapaan nama diri dengan profesi berkaitan dengan bidang pekerjaan yang dilakukan setiap harinya, misalnya, tukang, guru, dagang, toko dan lain sebagainya. Sedangkan sapaan nama diri dengan gelar berkaitan dengan sebutan kehormatan yang dimiliki seseorang, misalnya, haji, kyai, ustad, sarjana dan lain sebagainya.

\section{Data 24}

\section{Konteks :}

Pagi hari, 01 membeli sayuran di took 02 . Ketika 01 sedang memilih sayuran, datang seseorang (03) yang tidak diketahui identitasnya. Maka bertanyalah 01 kepada 02 tentang identitas 03.

\section{Tuturan :}

01 : "Lare kono mau sapa?"

[lare kono mau sopj]

'Anak barusan itu siapa?'

02 : "Anake Usnan lemu ika ya Wak."

[anake usnan ləmu iko yə $\mathrm{w}^{\mathrm{y}} \mathrm{a}$ ?]

'Anaknya Usman gemuk itu lho Wak'

01 : "Ye, duwe anak perawan"

[ye, duwe anak perawan]

'Oh, mempunyai anak gadis'

\section{Data 25}

Konteks :

Malam hari di rumah 01. Datang 02, yang merupakan adik 01 yang bertempat tinggal di desa Mangir, bermaksud memberikan undangan kepada 02 dari seorang temannya yang bertempat tinggal di Desa Mangir yang dititipkan kepadanya.

\section{Tuturan :}

01 : "Kang, iki rika ulih undangan"

[kay, iki riko Ulih und ${ }^{\mathrm{y}}$ anan]

'Kak, ini kamu dapat undangan'

02 : "Teka sapa?"

[təkJ sэp)]

'dari siapa?'

\section{1 : "Agus camat"}

[agUs camat]

'Agus camat'

Pada tuturan (24), merupakan penggunaan sapaan yang berkaitan dengan ciri fisik. Penggunaan sapaan ini untuk membedakan dua orang atau lebih yang memiliki nama sama. Dalam konteks tuturan (24), mitra tutur memberi tahu penutur tentang seseorang yang belum dikenalnya dengan mengatakan putri salah satu warga yang ada di kampungnya yaitu Usnan. Karena nama Usnan tidak hanya satu orang, maka mitra tutur memberikan penekanan nama Usnan dengan ciri fisiknya, Usnan gemuk. Dengan begitu penutur akan memahami nama seseorang yang dimaksud tersebut.

Pada tuturan (25), merupakan penggunaan sapaan berkaitan dengan profesi seseorang. Penggunaan ini juga untuk membedakan dua orang atau lebih yang memiliki nama sama. Dalam konteks tuturan (25), seorang adik yang memberi tahu kakaknya bahwa ia mendapat undangan pernikahan dari teman sekolahnya dulu, yang bernama Agus. Karena nama Agus lebih dari satu, maka sang adik memberi penekanan dengan menambahkan nama Agus dengan profesinya, Agus camat. Dengan begitu, diharapkan sang kakak akan memahami orang yang dimaksud tersebut.

\section{Deiksis Wacana dalam Bahasa Using}

Deiksis wacana dalam tulisan ini mencakup pengacu bagian sebelum saat tuturan dan pengacu bagian sesudah saat tuturan. Ekspresi deiksis wacana yang mengacu bagian sebelum saat tuturan yang ditemukan di antaranya adalah kata penunjuk (demonstrativa) iki 'ini' dan iku 'itu'. Kata penunjuk iki dapat berdiri sendiri sebagai ekspresi deiksis wacana untuk mengacu bagian wacana sebelum saat pengacuan, selain itu dapat berkombinasi dengan kata lain seperti nomina dan preposisi. Berikut dikemukakan data penggunaan deiksis wacana.

\section{Data 26}

Pelanggeran pemerintah 57 tahun 2014 ngenani Pengembangan, Pembinaan, dan Pelindungan Bahasa dan Sastra, serta Peningkatan Fungsi Bahasa Indonesia durung kabeh disosialisasikaken nyang masyarakat,....Pelanggeran $\underline{i k i}$ wis ngeweni arah nyang bangsa Indonesia, kadung bangsa hang gede iku wis duwe pesugihan Bahasa Daerah (BD) akehe 746 hang kesebar ring Nusantara. (LU, 2015, h.4).

"Peraturan Pemerintah 57 tahun 2014 tentang Pengembangan, Pembinaan, dan Perlindungan Bahasa dan Sastra, serta Peningkatan Fungsi Bahasa Indonesia belum semua disosialisasikan ke masyarakat...Peraturan ini sudah memberi 
arah kepada bangsa Indonesia, kalau bangsa yang besar itu sudah memiliki kekayaan Bahasa Daerah (BD) sebanyak 746 yang tersebar di Nusantara."

\section{Data 27}

Dino Sabtu tanggal 20 Nopember 2014, wis kaping pindo Pemerintah Kabupaten Banyuwangi nganakaken Festival Gandrung Sewu ring pesisir Boom. Kegiatan iku mau karepe kanggo mituhuni nang kesenian daerah. (LU, 2015, h.7)

"Hari Sabtu tanggal 20 Nopember 2014, sudah dua kali Pemerintah Kabupaten Banyuwangi mengadakan Festival Gandrung Sewu di Pantai Boom. Kegiatan itu tadi bermaksud untuk ... di kesenian daerah"

Pada data (26) pengacuan dengan iki berkombinasi dengan nomina pelanggeran. Kata penunjuk iki dalam kalimat pelanggeran iki wis ngeweni arah nyang bangsa Indonesia mengacu pada bagian wacana sebelum saat pengacuan dengan menghadirkan kembali nomina yang diacu yaitu Pelanggeran pemerintah 57 tahun 2014 ngenani Pengembangan, Pembinaan, dan Pelindungan Bahasa dan Sastra, serta Peningkatan Fungsi Bahasa Indonesia.Pada data (27) pengacuan kata penunjuk iku berkombinasi dengan nomina kegiatan danadverbia temporal mau. Kata penunjuk iku dalam kalimat kegiatan iku mau karepe kanggo mituhuni nang kesenian daerah mengacu pada bagian wacana sebelum saat pengacuan yaitu Festival Gandrung Sewu ring pesisir Boom.

Ekspresi deiksis yang ditemukan sebagai pengacu bagian wacana sesudah saat pengacuan adalah $i k i$ dan $i k u$. Dalam fungsinya sebagai pengacu, kata penunjuk iki berkombinasi dengan adverbia lokatif dan kata penunjuk iku berkombinasi dengan nomina dan adverbia temporal.

\section{Data 28}

Ngisor iki rangkuman materi nganggo dhasar kisi-kisi penulisan soal Basa Using kanggo kelas 6, hang dicithak kandel iku kunci jawabane.

\section{1) Kalimah takon, biasae nganggo ucap}

takon: sapa, paran, kelendi, nong endi,

wayakendi, apua. (LU, 2015, h.13)

"Di bawah ini rangkuman materi menggunakan dasar kisi-kisi penulisan soal
Bahasa Using untuk kelas 6, yang dicetak tebal itu kunci jawabannya.

1. Kalimat Tanya, biasanya menggunakan

kata tanya: siapa, apa, bagaimana, di

mana, kapan, mengapa."

\section{Data 29}

Kawigaten Balai Bahasa mau liwat Penelitian lan Pembinaan yang diwujudkan liwat penerbitan majalah basa daerah, dilakoni saat tahun 2008. Majalah iku mau yoiku Lontar Using (Basa Using), Titis Basa (Basa Jawa Krama), Ajisaka (huruf Jawa), lan Joko Tole (Basa Meduro). (LU, 2015, h.4).

"Asal mula Balai Bahasa tadi melalui Penelitian dan Pembinaan yang diwujudkan melalui penerbitan majalah bahasa daerah, dilakukan pada tahun 2008. Majalah itu tadi yaitu Lontar Using (Bahasa Using), Titis Basa (Bahasa Jawa Krama), Ajisaka (huruf Jawa), dan Joko Tole (Bahasa Madura)"

Pada data (28) kata penunjuk iki yang berkombinasi dengan adverbia lokatif ngisor mengacu pada bagian wacana sesudah saat pengacuan yang berupa rangkuman materi penulisan kisi-kisi soal, ngisor iki rangkuman materi nganggo dhasar kisi-kisi penulisan soal Basa Using kanggo kelas 6. Pada data (29) kata penunjuk iku yang berkombinasi dengan nomina majalah dan adverbial temporal mau mengacu pada bagian wacana sesudah saat pengacuan yang berupa nama-nama majalah yang akan diterbitkan, Majalah iku mau yoiku Lontar Using (Basa Using), Titis Basa (Basa Jawa Krama), Ajisaka (huruf Jawa), lan Joko Tole (Basa Meduro).

\section{PENUTUP}

Deiksis merupakan salah satu fenomena lingual yang universal karena ekspresiekspresi deiksis dapat ditemukan pada semua bahasa manusia, termasuk di dalam bahasa Using Banyuwangi. Deiksis persona dalam bahasa Using di Banyuwangi dalam penggunaannya dipengaruhi oleh perbedaan usia dan hubungan kekerabatan antara penutur dan mitra tutur.

Ekspresi demonstratif bahasa Using dalam penggunaannya merepresentasikan jarak relatif dekat kepada penutur, jarak relatif jauh dari penutur tetapi dekat kepada mitra tutur, dan jarak relatif jauh dari penutur 
dan mitra tutur. Dieksis ekspresi waktu diperoleh apabila penutur menjadi pusat deiksis saat waktu dihasilkannya tuturan. Dengan menjadikan saat tuturan sebagai pusat waktu, maka lokasi waktu suatu peristiwa terdapat sebelum (lampau), bersamaan (sekarang), dan sesudah saat tuturan (mendatang).

Deiksis sosial dalam bahasa Using berupa penggunaan kata sapaan, baik berkaitan dengan nama diri, istilah kekerabatan, gelar, profesi, jabatan, kepangkatan, kata nama, dan pronomina persona. Dalam deiksis wacana bahasa Using, demonstratif-lokatif lazim digunakan untuk menunjukkan hubungan antara bagian wacana yang diacu dengan lokasi terdapatnya pengacuan, baik yang mengacu pada bagian sebelum saat tuturan maupun pada bagian sesudah tuturan.

\section{DAFTAR PUSTAKA}

Ali, Hasan. (2002). Kamus Bahasa Daerah: Using Indonesia. Klaten: PT. Intan Pariwara.

Ali, Hasan. (2006). Tata Bahasa Baku Bahasa Using. Banyuwangi: Pemerintah Kabupaten Banyuwangi.

Hasibuan, Namsyah Hot. (2011). Deiksis dalam Bahasa Mandailing. Disertasi. Medan: Sekolah Pascasarjana Universitas Sumatera Utara.

Huang, Yan. (2007). Pragmatics. New York: Oxford University Press.

Lewis, M.P., Simons, G.F. dan Fennig, C.D. (Eds). (2015). Ethnologue: Language of the World.

Maesaroh, Siti. (2015). Penggunaan Bentuk Lingual Salam dan Sapaan dalam Masyarakat Using di Kecamatan Rogojampi Kabupaten Banyuwangi.Skripsi. Jember: Fakultas Sastra Universitas Jember.

Majalah Lontar Using. (2014). Basa Using ring Muatan Lokal (1). Edisi 7: Juli-Desember 2014. Surabaya. Halaman 13.

Majalah Lontar Using. (2015). Balai Bahasa sing Arep Mandeg Ngelestarekaken Basa Using. Edisi 8: Januari-Juni 2015. Surabaya. Halaman 4.

Mukarromah, Inayatul. (2016). Pengembangan Kesenian Banyuwangi Sebagai Langkah Tepat Guna Melestarikan Bahasa Oseng Di Berbagai Aspek. Prosiding Seminar Nasional Bahasa Ibu IX. 2627 Februari 2016. 1181-1193.

Purwo, Bambang Kuswanti. (1984). Deiksis Dalam Bahasa Indonesia. Jakarta: PN.Balai Pustaka.

Pusat Bahasa Departemen Pendidikan Nasional. (2003). Kamus Besar Bahasa Indonesia. Jakarta: Balai Pustaka.

Sahid, Ahmad. (2011). Deiksis dalam Bahasa Madura di Desa Kapongan Kecamatan Kapongan Kabupaten Situbondo: Suatu Tinjauan Semantik. Skripsi. Jember: Fakultas Sastra Universitas Jember.

Sudaryanto. (1993). Metode dan Aneka Teknik Analisa Bahasa. Yogyakarta: Duta Wacana University Press. 
Sugono, D. (2003). Buku Praktis Bahasa Indonesia 2. Jakarta: Pusat Bahasa Departemen Pendidikan Nasional.

Yule, George. (1996). Pragmatics. Oxford: Oxford University Press. 